\title{
Prevalence of asymptomatic bacteriuria among pregnant women in Kashmir
}

\author{
Shamweel Ahmad ${ }^{1}$, Shehla Shakooh ${ }^{2}$, Sajad Ahmad Salati ${ }^{3}$, Abdul Muniem ${ }^{4}$ \\ Sri Lanka Journal of Obstetrics and Gynaecology 2011; 33: 158-162
}

\begin{abstract}
Objective: To determine the prevalence of asymptomatic bacteriuria in pregnant women and antimicrobial susceptibility pattern of pathogens isolated and also to determine the relationship between asymptomatic bacteriuria and pyuria.
\end{abstract}

Methods: A total of 392 urine specimens were collected from 392 pregnant women with asymptomatic bacteriuria attending different antenatal care clinics for regular perinatal care between April, 2007 and July, 2008. All specimens were processed using standard microbiological procedures. All the subjects were evaluated for bacteriuria.

Results: The prevalence of asymptomatic bacteriuria was $6.1 \%$ among the pregnant women in Srinagar. From $92(23.5 \%)$ patients who had $\geq 5$ pus cells per high power field, only $15(16.3 \%)$ had positive urine culture. E.coli $(\sim 71 \%)$ was the commonest causative agent of asymptomatic bacteriuria followed by Klebsiella pneumoniae $(\sim 17 \%)$, group B Beta haemolytic Streptococcus (8.3\%) and Proteus mirabilis (4.2\%). Ciprofloxacin was found to be highly sensitive against all isolates.

Conclusion: Screening of bacteriuria in pregnancy and proper treatment must be considered as an essential part of antenatal care in this community. To prevent asymptomatic bacteriuria complications, all pregnant women should be screened at the first antenatal visit. A negative test for pyuria is not a reliable

\footnotetext{
${ }^{1}$ Department of Clinical Laboratory Sciences, College of Medical Sciences, Al-Kharj University, Saudi Arabia.

${ }^{2}$ Department of Obstetrics and Gynecology, S.K. Institute of Medical Sciences, Srinagar, Kashmir, India.

${ }^{3}$ Department of Surgery, King Fahd Medical City, Riyadh, Saudi Arabia.

${ }^{4}$ Department of Internal Medicine, S.K. Institute of Medical Sciences, Srinagar Kashmir, India.

Correspondence: Shamweel Ahmad

E-mail:drshamweel@hotmail.com
}

indicator of the absence of asymptomatic bacteriuria in pregnant women.

Key words: asymptomatic bacteriuria, pyuria, antenatal care, urinary tract infection, E. coli

\section{Introduction}

Urinary tract infection (UTI) is one of the most common diseases encountered in clinical practice today. Urinary tract infection is not only common but the range of clinical effect varies from asymptomatic bacteriuria to acute pyelonephritis ${ }^{1}$. Urinary tract infection is the commonest of all bacterial infections, affecting human beings throughout their life span especially in women ${ }^{2}$. Nearly $50 \%$ of all women develop symptoms of urinary tract infection at some stage during their life. Urinary tract infection account for more than 7 million visits to physicians and necessitate over 1 million hospital admissions in USA annually ${ }^{2}$. The urinary tract undergoes profound physiological and anatomical changes during pregnancy facilitating the development of bacteriuria both symptomatic and asymptomatic in women ${ }^{3}$. Symptomatic bacteriuria is the tip of an iceberg of total bacteriuria. Pregnancy is a provocation for the asymptomatic to become symptomatic ${ }^{4}$. About $10 \%$ of those with asymptomatic bacteriuria develop symptomatic bacteriuria during pregnancy ${ }^{5}$. Symptomatic bacteriuria is easily diagnosed and treated due to its overt symptoms. But asymptomatic bacteriuria is difficult to diagnose and it is more common in pregnant women than non-pregnant women ${ }^{6}$. In pregnancy, $30-40 \%$ of untreated pregnant women with asymptomatic bacteriuria develop acute pyelonephritis in late pregnancy ${ }^{7,8}$. Pyelonephritis is associated with significant morbidity during pregnancy for the mothers and the fetus. Thus, exact screening and treatment of bacteriuria regardless of symptoms is a must in order to avoid further complications ${ }^{9}$. Anatomic and physiologic changes that occur during the pregnancy increase the risk of pyelonephritis in this period ${ }^{9}$. This is mostly because pregnancy is a common cause of obstructive uropathy and thus results in severe renal infections. As pyelonephirits usually arises from preexisting bacteriuria; experts recommend screening and eradication of silent infections as routine prenatal 
practice $^{10}$. Early treatment of asymptomatic bacteriuria decreases the risk of pyelonephiritis in the later stages of pregnancy by atleast $75 \%{ }^{11}$. Also there is evidence that when there is no symptom, untreated bacteriuria in pregnancy may lead to less favorable pregnancy outcomes and complications like preterm delivery, low birth weight, pre-eclamptic toxemia and anemia of pregnancy ${ }^{7,12}$. Stenqvist and colleagues ${ }^{13}$ have shown that 18 weeks of gestation is the optimal time for performing screening culture for detecting bacteriuria. The present study was undertaken to determine the prevalence of asymptomatic bacteriuria in pregnancy; its causative agents and their antimicrobial susceptibility pattern, and also to determine the relationship between asymptomatic bacteriuria and pyuria.

\section{Materials and methods}

The study was conducted in the city of district Srinagar, Kashmir, India. A total 392 urine specimens were collected from asymptomatic bacteriuric women during April, 2007 to March, 2008. All subjects were examined at the first antenatal visit and maximum gestational age was 18 weeks. None of the patients had any signs or symptoms of classical UTI on examination. Asymptomatic bacteriuria was defined as the presence of $\geq 10^{5} / \mathrm{ml}$ colonies of the same bacterial species in two consecutive midstream urine without any symptom of urinary tract infection. On each visit, two consecutive midstream clean catch urine samples, one on the day of the visit and another on the next day of the visit, were collected in a sterile wide mouth screw capped container with aseptic precautions. The patients were individually instructed about the technique for collecting clean voided midstream urine specimens. All patients were asked to wipe their labia with soapy water and rinse well, then after urinating a little in the toilet fill the container (clean catch method). All the specimens were sent to the microbiology laboratory and processed on the same day. Standard microbiological techniques were used in the culture of all MSU specimens and in the identification of the isolates. One $\mu \mathrm{l}$ of uncentrifuged urine specimens were aseptically inoculated, using standard loops, onto sheep blood agar (SBA) plates containing $6 \%$ blood and cysteine lactose electrolyte deficient (CLED) agar plates. The plates were incubated aerobically for 24 to 48 hours at $37^{\circ} \mathrm{C}$. The plates were read at the end of the incubation period. Colony counts equal to or more than $10^{5} / \mathrm{ml}$ was considered as significant growth.

Antibiotic susceptibility testing was carried out using the Kirby-Bauer disc diffusion technique on Muller-Hinton agar and commercial antibiotic discs
(Oxoid, United Kingdom) were used for antimicrobial testing ${ }^{14}$. The antibiotic discs used were: Ampicillin $(10 \mu \mathrm{g})$, Naldixic Acid $(30 \mu \mathrm{g})$, nitrofurantoin (300mg), Cephalexin $(30 \mu \mathrm{g})$, Gentamicin $(10 \mu \mathrm{g})$, TrimethoprimSulphamethoxazole (1.25/ $23.75 \mu \mathrm{g})$ and Ciprofloxacin $(5 \mu \mathrm{g})$. The antibiotic disc impregnated culture plates were incubated at $37^{\circ} \mathrm{C}$ overnight. The diameter of the zone of inhibition was measured and recorded as resistant or susceptible according to the National Committee for Clinical Laboratory Standards (NCCLS) interpretative criteria ${ }^{15}$. For the test of proteinuria, the end of the reagent strip was dipped in the fresh urine for approximately 1 second and shaken off by tapping the strip on the side of the container. After 30 to 60 seconds the test strip was compared with the color scale (color range from yellow for "negative" and through yellow-green and green blue for "positive"). For microscopy about $10 \mathrm{ml}$ of well-mixed urine sample was centrifuged at $2000 x y$ for 5 minutes. A drop of the deposit was examined microscopically at 40x for the presence of pus cells, red blood cells, epithelial cells, casts and crystals.

The Statistical Package for Social Sciences (SPSS, version 10.1) was used for data analysis. The results are expressed as mean value \pm standard deviation. Chi-square test was used for comparison between groups. A two-tailed $p$-value less than 0.05 was considered statistically significant.

\section{Results}

The total number of participants who finished the study was 392. The mean age of the participants was $27.4 \pm 3.1$ (range, 19-37 years). Of the 392 urine specimens processed, 24 (6.1\%) showed significant bacteriuria. Thus the prevalence of different types of causative organism of significant bacteriuria was $6.1 \%$. The frequency of the microorganisms isolated is shown in Table 1. The commonest organism causing bacteriuria was Escherichia coli. The sensitivity pattern of the isolated organisms revealed that all were sensitive to ciprofloxacin and gentamicin at very high percentage (Table 2). The organisms showed resistance to currently preferred urinary antibiotics and chemotherapeutic agents like co-trimoxazole, norfloxacin, and cephalexin (Table 2). Ninety-two $(23.5 \%)$ women had more than 5 pus cells in urine specimens from which $15(16.3 \%)$ had positive cultures. Association of presence of pus cells with bacterial growth is shown in Table 3. Women with higher number of pus cells in urine specimen had significantly higher asymptomatic bacteriuria $(p<0.0001)$. 
Table 1. Microorganisms isolated in positive cultures

\begin{tabular}{lcc}
\hline Isolates & Number & $(\%)$ \\
\hline Escherichia coli & 17 & $(70.8)$ \\
Klebsiella & 4 & $(16.7)$ \\
Group B Streptococcus & 2 & $(8.3)$ \\
Proteus mirabilis & 1 & $(4.2)$ \\
Total & 24 & $(100)$ \\
\hline
\end{tabular}

Table 2. Antimicrobial susceptibility pattern of organisms causing bacteriuria in pregnant women

\begin{tabular}{lcccc}
\hline Antimicrobial drug & \multicolumn{4}{c}{ Causative bacteria } \\
\cline { 2 - 5 } & E. coli & Klebsiella & $\begin{array}{c}\text { Group B } \\
\text { Streptococcus }\end{array}$ & Proteus \\
\hline Ciprofloxacin & $\%$ & $\%$ & $\%$ & $\%$ \\
Gentamicin & 96.9 & 93.1 & 100.0 & 100.0 \\
Ampicillin & 96.2 & 93.1 & 72.2 & 85.0 \\
Nitrofurantoin & 46.3 & 0.0 & 35.1 & 10.0 \\
Cephalexin & 55.1 & 43.1 & 74.2 & 0.0 \\
Nalidixic acid & 38.0 & 29.2 & 27.7 & 15.4 \\
Co-trimoxazole & 48.0 & 52.5 & 48.6 & 31.1 \\
\hline
\end{tabular}

Table 3. Association of pus cells with bacterial growth

\begin{tabular}{cccccc}
\hline Number of pus cells & Number of patients & $\begin{array}{c}\text { Positive culture } \\
\text { Number (\%) }\end{array}$ & $\begin{array}{c}\text { Negative culture } \\
\text { Number (\%) }\end{array}$ & p-value \\
\hline 0 & 251 & $4(1.6)$ & $247 \quad(98.4)$ & \\
$1-4$ & 49 & $5(10.2)$ & $44 \quad(89.8)$ & $p<0.0001$ \\
$>5$ & 92 & $15(16.3)$ & $77 \quad(83.7)$ & \\
Total & 392 & $24(6.1)$ & 368 (93.9) & \\
\hline
\end{tabular}




\section{Discussion}

Urinary tract infections are remarkably common in women. Some $20 \%$ women in the age range 20-65 years suffer from at least one attack per year, $50 \%$ develop a urinary tract infection within their life time ${ }^{16}$. Not surprisingly infections of the urinary tract are the most common bacterial infections encountered during pregnancy. These can be both symptomatic and asymptomatic. Asymptomatic bacteriuria during pregnancy is a common and important medical condition, which will result in overt renal infections such as pyelonephirits if not detected and treated ${ }^{17}$. Smaill ${ }^{18}$ showed that on an average treating 7 pregnant women with asymptomatic bacteriuria results in prevention of one episode of pyelonephirits. Ten percent of pregnant women attended in an antenatal clinic had symptomatic urinary tract infections ${ }^{4}$. In another study by Khatun et al. (1985) ${ }^{6}$, it was found that $30 \%$ of clinically healthy pregnant women had asymptomatic bacteriuria. Findings of the present community based study indicate that the asymptomatic bacteriuria in pregnancy is a major health problem in Srinagar city. Observed from this study that E. Coli was the commonest pathogen responsible for bacteriuria. It is consistent with the findings of Rahman et al. (1990) ${ }^{19}$ and Ahmed et al. $(1996)^{20}$. Like the other studies ${ }^{16,21,22}$ the findings of our study also indicate that ciprofloxacin is highly effective. The most effective in-vitro agents were found to be gentamicin among the injectables and ciprofloxacin among the orally administered ones. Other useful oral antibiotics were nitrofurantoin and nalidixic acid. The organisms showed resistance to currently preferred urinary antibiotics and chemotherapeutic agents like co-trimoxazole and cephalexin. Our findings were in agreement with a study from Kashmir ${ }^{22}$. It may probably be due to less use of ciprofloxacin since it is comparatively a newer introduction and also costly. This fact indicates that urinary pathogens became resistant day by day to the commonly used antibiotics in our country. This may be due to wide spread and indiscriminate use of the drugs. There are many studies ${ }^{16,23-25}$ that link so many pregnancy compli-cations like hypertensive disorders in pregnancy, low birth weight, premature with symptomatic bacteriuria. Moreover, for the last two decades, asymptomatic bacteriuria has also been identified as a risk factor of similar pregnancy complications ${ }^{16}$. The results of the present study also agree with these findings. The association between asymptomatic bacteriuria and prematurity is established ${ }^{7,8,12}$. But the mechanism is not well defined yet. Several investigators have observed a high incidence of pyelone-phritis in bacteriuric pregnant mothers ${ }^{7,8}$.
In this study, prevalence of asymptomatic bacteriuria was found to be $6.1 \%$, which is in agreement with others ${ }^{26}$. We also found that asymptomatic bacteriuria was associated with lower maternal age. The prevalence of asymptomatic bacteriuria was reported to be as high as $21 \%$ in a study from Ibadan city, Nigeria ${ }^{9}$ and $86.6 \%$ in another study from Benin City, Nigeria ${ }^{27}$. Significant pyuria with bacteriuria was found in $62 \%$ of our patients. So the presence of significant pyuria should not be used as a screening test for asymptomatic bacteriuria in pregnancy. Using this method for screening of asymptomatic bacteriuria in this study would have obtained a false negative rate of $40 \%$. This is consistent with the results of other studies. Two studies found that there was only $50 \%$ significant pyuria with positive cultures ${ }^{9,28}$.

Pyuria was found in $21 \%$ of negative cultures. In two others studies, 9,28 pyuria has been reported in up to $30 \%$ and $23 \%$ of negative cultures. They concluded that all samples should be sent for culture, because none of the rapid tests, including the screen for pyuria, are reliable for detecting asymptomatic bacteriuria in pregnant women ${ }^{9,28-30}$. Wadland and colleagues ${ }^{31}$ showed that screening for asymptomatic bacteriuria is cost saving unless the prevalence of asymptomatic bacteriuria falls below $2 \%$, the risk of pyelonephritis with asymptomatic bacteriuria falls below $13 \%$, or the efficacy of treatment in preventing pyelonephritis falls below $38 \%$. Thus, in our region, this intervention remains cost saving Finally, in accordance with Stenqvist and colleagues ${ }^{13}$, we chose 18 weeks gestation as the optimal time to perform the screening culture in order to maximize the chances of detecting bacteriuria. However, in North America the current approach is to screen for asymptomatic bacteriuria at 12 weeks of gestation ${ }^{32}$.

In conclusion, screening for bacteriuria in pregnancy and proper treatment must be considered as an essential part of antenatal care in this community. A negative test for pyuria is not a reliable indicator of the absence of asymptomatic bacteriuria in pregnant women. Thus, all urine specimens, regardless of leukocyte count, should be sent for culture and sensitivity.

\section{References}

1. Ahmed S, Rashid HU. Urinary tract infection in adults: a review. Bangladesh Renal J 1996; 15: 23-31.

2. Patton JP, Nash DB, Abrutyn E. Urinary tract infection: economic consideration. Med Clin North Am 1991; 75: 64, 495-513.

3. Begum N. Clinical profile of urinary tract infection in pregnancy. Mymensingh Med J 1992; 1: 6-10. 
4. Doland I. Practical obstetric problems. 5th ed. London, Lloyd-luke Ltd., 1979.

5. Bailey RR. Urinary tract infection. Can Ded Assoc 1972; 107: 315-30.

6. Khatun AK, Rashid H, Chowdhury TA. Prevalence of urinary tract infection in pregnancy. J Bangladesh Coll Phys Surg 1985; 2: 6-10.

7. Joseph KS, Brahmadathan KN, Abraham S, Joseph A. Detecting bacteriuria ia a primary maternal and child health care program. Bri Med J 1988; 296: 906-7.

8. Turner AN, Savill J, Stewart LH, Cumming A. Kidney and genitourinary disease. In: Davidson's Principles and practice of medicine. Haslett C, Chilvers ER, Boon NA, Colledge NR (eds). 19th ed. Edinburgh, Churchill Livingstone, 2002, pp 575-639.

9. Macejko AM, Schaeffer AJ. Asymptomatic bacteriuria and symptomatic urinary tract infections during pregnancy. Urol Clin North Am 2007; 34: 35-42.

10. Sheffield JS, Cunningham FG. Urinary tract infection in women. Obstet Gynecol 2005; 106: 1085-92.

11. Nicolle LE, Bradley S, Colgan R, Rice JC, Schaeffer A, Hooton $\mathrm{TM}$, et al. Infectious Disease Society of America guidelines for the diagnosis and treatment of asymptomatic bacteruria in adults. Clin Infect Dis 2005; 40: 643-54.

12. Roony C. Antenatal care and maternal health: how effective is it? Maternal Health and Safe Motherhood Programme, Division of Family Health, World Health Organization, 1992.

13. Stenqvist K, Dahlén-Nilsson I, Lidin-Janson G, Lincoln K, Odén A, Rignell S, et al. Bacteriuria in pregnancy. Frequency and risk of acquisition. Am J Epidemiol 1989; 129: 372-9.

14. Bauer AW, Kirby WMM, Sherris JC, Jurek M. Antibiotic Susceptibility testing by a standardized single method. Am J Clin Pathol 1996; 45: 493-6.

15. Performance standards for antimicrobial susceptibility testing. Tenth informational supplement. National Committee for Clinical Laboratory Standards (NCCLS), January 2000: M100-S10 (M2): 14-21.

16. Gilstrap LC, Leveno KJ, Cunningham FG, Whalley PJ, Roark ML. Renal infection and pregnancy outcome. Am J Obstet Gynecol 1981; 141: 709-16.

17. Smaill F. Asymptoamtic bacteriuria in pregnancy. Best Parct Clin Obstet Gynecol 2007; 21: 439-50.

18. Smaill F. Antibiotics for asymptomatic bacteriuria in pregnancy. Cochrane Database Sys Rev 2001; 2: CD 000490.
19. Rahman T, Haque F, Begum J, Khan IH. Urinary tract infection in diabetic and non-diabetic patients: a comparative study. Bangladesh Renal J 1990; 9: 8-12.

20. Ahmed I, Siddique MA, Rahman MM, Ali MS, Nessa J, Alam ABMM. Bacterial etiology and antimicrobial susceptibility pattern of suspected UTI cases. Mymensingh Med J 1996; 5: 86-90.

21. Ahmed S, Jahan RA, Alam E. Bacteriologic etiology and sensitivity pattern of different drugs in urinary tract infection in adult. Bangladesh Renal J 1999; 18: 9-12.

22. Kadri SM, Gash B, Rukhsana A. Antibiotic sensitivity and resistance profile of the micro-organisms responsible for urinary tract infection observed in Kashmir, India. J Indian Med Assoc 2002; 100(11): 656, 658-60.

23. Truck M, Goffe BS, Petersdrof RG. Bacteriuria of pregnancy: Relation to socioeconomic factors. N Engl J Med 1966; 266: 857-60.

24. Sever JL, Ellenberg JH, Edmonds D. Urinary tract infections during pregnancy: Maternal and pediatric findings. In: Infections of the urinary tract. Kass EH, Brumfitt W (eds). Chicago, University of Chicago Press, 1975, pp. 129-21.

25. Kass EH, Zinner SH. Bateriuria and pyelonephritis in pregnancy. In: Obstetric and perinatal infections. Charless D, Finland M (eds). Philadelphia, Lea \& Febiger, 1973, pp 407-46.

26. Hazhir S. Asymptomatic bacteriuria in pregnant women. Urol J 2007; 4: 24-7.

27. Akerele J, Abhulimen P, Okonofua F. Prevalence of asymptomatic bacteriuria among pregnant women in Benin City, Nigeria. J Obstet Gynecol 2001; 21: 141-4.

28. Bachman JW, Heise RH, Naessone JM, Timmerman MG. A study of various tests to detect asymptomatic urinary tract infections in an obstetric population. JAMA 1993; 270: 1971-4.

29. Hagay Z, Levy R, Miskin A, Milman D, Sharabi H, Insler V. Uriscreen, a rapid enzymatic urine screening test: useful predictor of significant bacteruria in obstetric patients. Obstet Gynecol 1996; 87: 410-3.

30. Kacmaz B, Cakir O, Aksoy A, Biri A. Evaluation of rapid urine screening tests to detect asymptomatic bacteriuria in pregnancy. Jpn J Infect Dis 2006; 59: 261-3.

31. Wadland WC, Plante DA. Screening for asymptomatic bacteriuria in pregnancy a decision and cost analysis. J Fam Pract 1989; 29: 372-6.

32. Nicolle LE. Asymptoamtic bacteriuria: review and discussion of the IDSA guidelines. Int J Antimicrob Agents 2006; 28: S42-S48. 